\title{
Institutional Role in Implementing Climate Action (SDG 13): A Case Study from the University of Colombo, Sri Lanka
}

\author{
Erandathie Lokupitiya ${ }^{1} \&$ Madumi Kariyawasam ${ }^{2}$ \\ 1. Professor in Environmental Science, Dept. of Zoology and Environment Sciences, University of \\ Colombo \\ 2. Former Environmental Officer, Center for Environmental Initiatives, University of Colombo
}

\begin{tabular}{l} 
ABSTRACT \\
Climate change has been identifiedas one of the biggestenvironmental \\
issues of the century. Since the industrial revolution, fossil fuel burning and \\
deforestation due to human activities have increased levels of greenhouse \\
gas (GHG) emissions, leading to global warming and climate change. One of \\
the key Sustainable Development Goals (SDGs) under the 2030 Agenda for \\
Sustainable development is SDG 13 on climate action, which was adopted \\
in parallel to the Paris Agreement of 2015. Sri Lanka has been identified \\
as a highly vulnerable country to climate change, and institutionally led \\
climate action is essential in achieving the country's overall climate change \\
mitigation targets. This article is based on a study which had, as its objective, \\
the evaluation of such mitigation action at an institutional level, considering \\
evidence from the University of Colombo, Sri Lanka. The available data at the \\
university on climate action was analyzed. Increasing the use of renewable \\
energy, energy saving appliances, water conservation measures, zero waste \\
strategies, and expanding the vegetation (especially the forest cover), are \\
required, as evidenced from the University of Colombo. The overall emission \\
estimates indicate that there has been a remarkable emission reduction at \\
the University due to the shift to cleaner and energy saving options and \\
waste management practices adopted since 2017. To achieve SDG 13's \\
targets, individual, institutional, and national level commitments are required. \\
Attitudinal change and awareness creation among the community are key \\
components in promoting and developing such commitments. \\
KEYwoRDS: \\
Sustainable Development Goals, SDG 13, Climate Action, University of \\
Colombo, Institutional role, climate change \\
\hline
\end{tabular}

Suggested Citation: Lokupitiya, E. \& Kariyawasam, M. (2021). Institutional Role in Implementing Climate Action (SDG 13): A Case Study from the University of Colombo, Sri Lanka. University of Colombo Review (New Series III), 2(2), $162-170$.

(C) 2021 The Authors. This work is licenced under a Creative Commons Attribution 4.0 International Licence which permits unrestricted use, distribution, and reproduction in any medium, provided the original work is properly cited. 


\section{Introduction}

Climate change has emerged as one of the biggest environmental concerns of the century due to its devastating impact on society and the environment. The world has experienced the negative impacts of climate change despite certain benefits gained by a few countries in shifting to a warmer climate.

Since the industrial revolution, fossil fuel burning and deforestation activities have increased globally, leading to increased levels of greenhouse gas (GHG) emissions including carbon dioxide $\left(\mathrm{CO}_{2}\right)$, causing global warming and climate change (Houghton, 2004). The Paris Agreement, which was adopted in 2015 during the 21st Conference of Parties (COP 21) of the United Nations Framework Convention on Climate Change (UNFCCC), has the ambitious target of keeping the rise in temperature well below $20 \mathrm{C}$ (and preferably $1.50 \mathrm{C}$ ) compared to the pre-industrial levels, by the end of this century. In achieving this target, all member countries have a universal responsibility (UNFCCC, 2021). While the Paris Agreement essentially targeted only climate change, in 2015, the UN General Assembly of 193 member countries adopted 17 Sustainable Development Goals (SDGs) under the 2030 Agenda for Sustainable Development. The aims of these SDGs are poverty alleviation, reducing inequality, and tackling climate change towards a more sustainable future for the world by the year 2030 (United Nations, 2015). Of these 17 goals, SDG 13 on Climate Action is one of the key SDGs.

As a country, Sri Lanka has ratified all the important international treaties related to climate change including the UNFCCC, the Kyoto Protocol, and the Paris Agreement. The country has already incorporated SDGs into its policy making process, and the Sustainable Development Act of 2017 has provided the legal framework for the proper implementation of the SDGs with required institutional development including the establishment of a Sustainable Development Council. Thus, as a country, since its ratification of the UNFCCC in November 1993, Sri Lanka has been involved both nationally and globally on climate action. As an island Sri Lanka is highly vulnerable to climate change and was ranked no. 2 under the Global Climate Risk Index in 2019, based on 2017 data (Eckstein et al., 2019).

Climate action under SDG13 means taking urgent action to combat climate change and its impacts. SDG 13 and the temperature target of the Paris Agreement should go hand-in-hand. To limit the temperature rise by the end of this century to less than $1.5^{0} \mathrm{C}$ above the pre-industrial levels the world should reach net zero GHG emissions by 2050, an unrealistic and ambitious target. Under the Paris Agreement, the member countries including Sri Lanka, have developed Nationally Determined Contributions (NDCs) for key economic sectors involving GHG emissions and climate change impacts. However, due to the unexpected economic downfall across the globe with the COVID-19 pandemic, overall socioeconomic development and anticipated emission levels have been much lower during the year 2020 (Le Quéré et al., 2020).

Given the impacts the country has been experiencing in various economic sectors, Sri Lanka needs to take immediate action on SDG 13. A bottom-up approach is essential, starting from the institutional level scaled up to the national level. Among the institutions, higher education institutions could play a key role, given their knowledge and research capacity. 


\section{Case Study: Climate action by the University of Colombo}

Greenhouse gas emissions leading to climate change occur mainly due to human activities involving fossil fuel burning, mostly in the power, industry, and transport sectors. The shift to low carbon solutions, or options with lower GHG emissions is essential for reaching carbon neutrality by 2050 . The case study on which this article is based focused on how the University of Colombo, the oldest university in Sri Lanka, has responded to this challenge.

The main premises of the University of Colombo is located in the heart of the capital, Colombo. It was with the Ceylon Medical College, founded in 1870, and the Ceylon University College founded in 1921 that the university was formed. Today, it has nine faculties with 56 academic departments, a Campus, a School, 7 Institutes and 8 Centres and Units. Many undergraduate and postgraduate study courses in the fields of Arts, Science, Medicine, Management, Finance, Law, Education, IT, Aesthetic Studies, Mass Media, Molecular Biology, Health Sciences etc., are conducted by the university. It also offers several other services such as library information services, career guidance, and services for differently-abled students.

Energy (electricity generation), transport, industry, waste, and forests have been identified as the sectors most in need of attention for Sri Lanka to reach its targets under the Paris Agreement and SDG 13 (Ministry of Environment, 2021). Our case study analyzed each of these sectors except for industry, which was replaced by water.

\section{Methodology}

The data relevant to climate action (i.e., data from sectors with potential mitigation of greenhouse gas emissions) from the University of Colombo was obtained for the period 2017-2019. The data was compiled by the University's Center for Environmental Initiatives. The specific data used for the analysis included annual energy consumption, water consumption, and waste generation and management by type, considering biodegradable and non-biodegradable waste types.

The data was variably used across the sectors to derive a meaningful assessment. The overall assessment focused on the contribution of the University as an institution representing the higher education sector in Sri Lanka. The analysis was carried out in line with climate change- and sector-specific national circumstances and policy frameworks within the country.

\section{SDG 13 and energy solutions}

The energy sector has the highest potential for implementing climate and energy efficient solutions. Sri Lanka as a country had up to $80 \%$ of electricity generation through hydro power until several decades ago. By the dawn of the century, $70 \%$ of the country's power requirement was met by hydropower, which is a renewable energy source with no GHG emissions (Lokupitiya, 2002). The hydro power contribution to the national grid was about $50 \%$ by 2010 , and since the initiation of coal-fired power generation in 2011 , the 
thermal power percentage including both coal and fuel oil has been around $50 \%$ annually. This increases to over $80 \%$ during drought periods. Although there are non-conventional renewable energy sources such as mini-hydro, solar, and wind, their contribution to the national grid has been $5 \%$ or less. The thermal power share in the grid electricity is what leads to GHG emissions. The country has plans to increase its renewable energy share in the national grid supply in the future. Such mitigation action should be promoted at both institutional and national levels.

Currently, the main share of Sri Lanka's total GHG emissions comes from the energy sector which includes electricity generation and transport. Energy conservation and efficiency have been identified as key measures in lowering energy-related GHG emissions (IPCC, 2011). In enhancing energy conservation, awareness creation among the community is important. Energy use in buildings needs to be minimized. Simple good practices such as shifting to more energy saving bulbs such as CFLs and LEDs, installing energy saving appliances including refrigerators and air conditioners, installing and switching on only the required number of lights, and switching off any unused lights, fans, and A/Cs, need to be encouraged at institutional level to minimize energy use and reduce energy-related GHG emissions. The annual electricity consumption at the University of Colombo across all its faculties, institutes, campus, centers, and hostels during 2018 and 2019 was 7,142,866 kWh (i.e. $7.1 \mathrm{GWh}$ ) and 9,282,998 kWh (i.e. $9.3 \mathrm{GWh}$ ) respectively. The per person electricity usage in 2019 was $346.35 \mathrm{kWh} /$ person. The percentage of energy efficient LED bulbs in use was $32 \%$ (remainder being CFL), and energy saving inverter air conditioners constituted $40 \%$ of the air conditioners in 2019. Currently, LED lighting is used in all new buildings, and CFL bulbs are being replaced with LED bulbs. There is still some potential to mitigate energy-related emissions. by further shifting to energy saving appliances.

The use of renewable energy sources in Sri Lanka has increased recently. Shifting to solar power for at least part of the power consumption, adopting measures for enhancing the use of natural ventilation and daylight, creating a shady environment with trees and creepers on walls (i.e., vertical gardens), proper choice of wall and roof materials to minimize the need for cooling etc. need to be further encouraged at institutional and household levels. At the University of Colombo, the Faculty of Management and Finance has installed solar panels with a capacity of $37.4 \mathrm{kVA}$ (i.e. $\sim 30 \mathrm{~kW}$ ), to generate electricity using solar energy. The solar electricity thus generated is utilized for lighting the 3 -storey building and is sufficient for all the bulbs currently in use in the building. Solar power has also been used for outdoor lighting at the Institute of Agro-technology and Rural Sciences (UCIARS) of the University. Furthermore, biogas generating plants at the Faculty of Technology and UCIARS are used as a method of resource recovery and as a renewable energy source (Figure 1). 


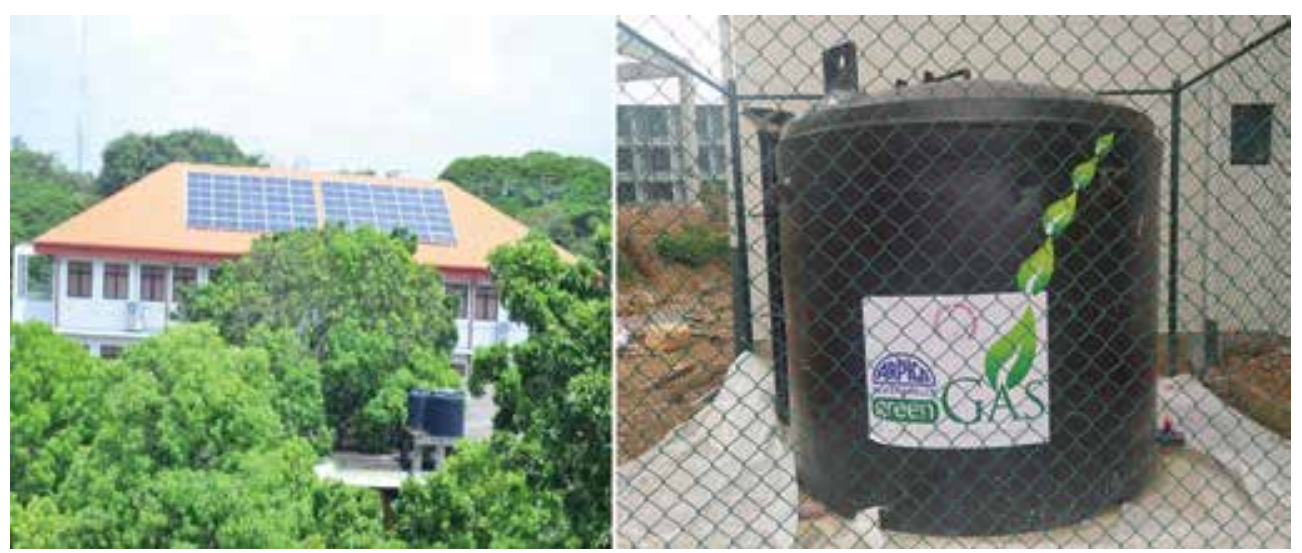

Figure 1

Renewable energy sources at the University of Colombo: Roof solar panels at the Faculty of Management and Finance (left), and mini biogas plant at the Faculty of Technology (Source/s: Faculties of Management and Finance, and Technology)

Green, smart buildings help institutes to reduce energy needs and minimize greenhouse gas emissions. By 2019, the University of Colombo had a smart building area of $112974 \mathrm{~m}^{2}$, which covered $27 \%$ of its total building area. This percentage has been rapidly increasing, as all new buildings constructed have more green and smart elements.

To reduce emissions in the transport-sector, a more passenger-friendly public transport system is important. Although the COVID-19 pandemic affected the number of private vehicles on the road, the population of motor cars and motorcycles increased by 37 \% from 2015 to 2019 (Ministry of Transport, 2021). Carpooling options and a passengerfriendly public transport systems will help reduce GHG emissions in the long run. Proper law enforcement on roads and promoting non-motorized transport options such as cycling and walking is essential, although the country has maintained good walking paths and other facilities for pedestrians in most urban areas. The above options need to be promoted at institutional level too with measures to minimize vehicle-travel. Regular shuttle services for employees need to be considered to minimize transport-related GHG emissions in line with SDG 13.

\section{Water conservation and SDG 13}

Currently pipe borne water is provided to $43.4 \%$ of Sri Lanka's population by the National Water Supply and Drainage Board (NWSDB). Water has become a scarce resource in certain parts of the country, and pumping of water requires electricity, leading to GHG emissions. To minimize the emissions in the water sector, the most effective option is to reduce wastage of pipe borne water. Rainwater harvesting and reusing treated wastewater for gardening and flushing toilets have been practiced at institutional level. The use of sensor taps and regulated sprinkler irrigation systems for gardens, especially during drought periods, will also help improve the efficient use of water while reducing emissions. 
The Faculty of Graduate studies of the University of Colombo has a rainwater harvesting system which is used for flushing toilets. The Institute for Agro-Research and Rural Sciences of the University in the Hambanthota District has a larger natural tank area which facilitates the storage of rainwater for use in farming (Figure 2). It covers a 25 acre-feet area, serving as a water conservation source. Wastewater treatment facilities and sewage treatment plants are available at the Faculties of Management and Finance, and Technology. Currently, the quality of the treated water is suitable for gardening. Such use of recycled water could reduce the consumption of pipe borne water from the national water supply.

Water efficient appliances such as urinals with automatic flush control, low flush toilets, and low flow/ automatic taps have been installed in many buildings within the University. The University ensures that such appliances are installed in buildings under renovation, and in new constructions. These facilities are available in the Faculties of Arts, Management and Finance, and Technology.

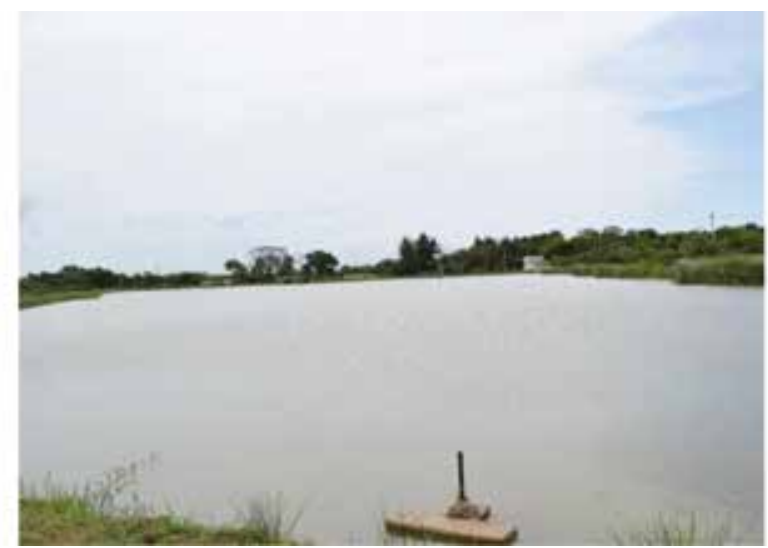

Figure 2

25 Acre-feet tank area of UCIARS (Source: UCIARS)

\section{Waste Management}

Waste is a major GHG sector, where improperly dumped, mixed waste can lead to methane emissions (IPCC, 2006). As a country, Sri Lanka has implemented proper waste segregation, overseen by local authorities, and this has been practiced at institutional level as well. However, although policy level decisions have been taken at various times on banning polythene/plastic waste, the implementation of such policy measures has not been successful. In line with the government policy decision to ban single-use plastics, the University of Colombo was made a 'polythene-free zone' in 2017, and students and staff were made aware of this as well as the waste segregation practices through notices and faceto-face awareness sessions. Students were informed of this policy during their orientation program. An annual waste survey has been conducted since 2017 to quantitatively analyze waste generation on the main university campus. Over time there has been a reduction in polythene/plastic waste (Figure 3), which could also be attributed to the cessation of the 
use of polythene lunch sheets in canteens. According to canteen sources, the ban on the use of lunch sheets on plates has prevented the use of over one million lunch sheets annually. According to the annual waste surveys conducted, the total annual reduction in polythene waste after the implementation of the polythene-free policy for one year was 1.752 tonnes, and newly introduced waste management practices at the University, including waste segregation, have prevented an annual emission of 265 tonnes of $\mathrm{CO}_{2}$ equivalent $\left(\mathrm{CO}_{2} \mathrm{e}\right)$ greenhouse gases from landfill sites (Kariyawasam \& Lokupitiya, 2018).

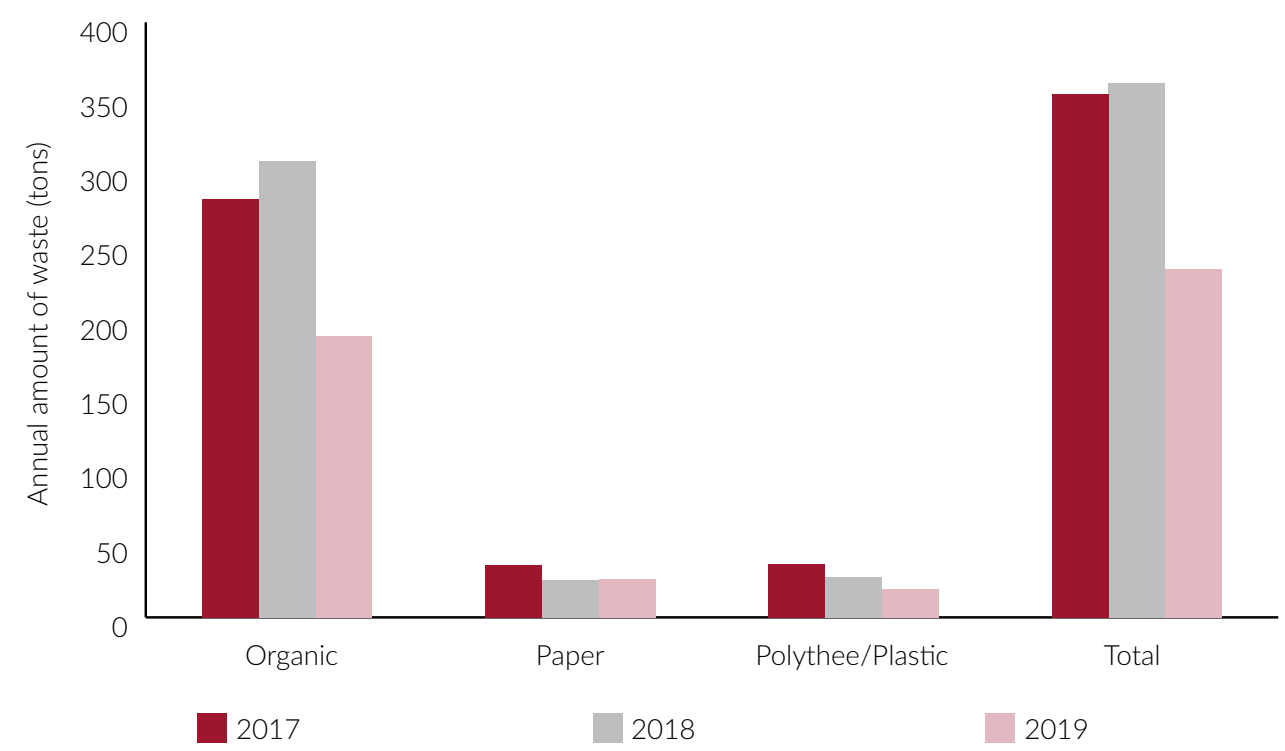

Figure 3

Annual waste generation at the main campus of the University of Colombo

The Waste Storage Centre of the University of Colombo was opened in 2019, with the support of the Central Environmental Authority of Sri Lanka. Its purpose is to store recyclable waste (i.e. paper, plastic/polythene, glass, and metal) which would have otherwise ended up in landfill sites. The stored waste is taken away periodically by recycling companies. With the initiatives taken so far, plastic waste generation on the premises has been nearly halved, showing a decrease from 35.5 tonnes in 2017 to 19.2 tonnes in 2019 . Moreover, by segregating the waste, the University has been able to avoid contributing to waste-related methane emissions at landfill sites.

The banning of polythene lunch sheets at canteens, introducing the use of lunch boxes and alternative product such as cloth bags and metal straws, green talks and awareness programs for canteen, janitorial, academic and non-academic staff, and students have helped the overall waste reduction on the premises (See Figure 3). However, the targeted zero single-use plastics on campus has occurred at a slower pace than expected. This is due to lunches being brought in from other sources including street vendors. The reluctance to change by a minority has also added to the challenge. Canteens continue to be a major source of organic waste, and $75 \%$ of the food waste is sent to piggeries for animal feed, while the remaining food waste is disposed of in mixed form (i.e., mixed with wrappers etc.) 
and taken away by the Municipal Council for dumping at landfills sites. Small composting facilities for treating organic waste (mostly garden waste) are available on the premises of a majority of the faculties and the institutes. Larger facilities are also available at the Faculty of Arts and the UCIARS. The compost produced is used as fertilizer for gardening within the University.

\section{Enhancing vegetation cover for climate and carbon footprint benefits}

Vegetative ecosystems, mostly forests, help offset carbon emissions by absorbing carbon dioxide from the atmosphere. The forest cover of Sri Lanka was 29.7\% in 2017, and the plan at national level is to increase it to $32 \%$ by 2030 (Ministry of Environment, 2021). Currently, the vegetation cover (including grass cover) at the University of Colombo is $35 \%$ of its total area, amounting to 49,399.85 $\mathrm{m}^{2}$, including the Sri Palee Campus which is located in a suburban area but has a significant forest cover of $35,000 \mathrm{~m}^{2}$. The further expansion of forested areas has been planned, which will also help towards achieving carbon neutrality. The University has been calculating its carbon footprint, which indicates the total emission of greenhouse gases, since 2014 at the Faculty of Science, and the entire institution since 2019. Its carbon footprint (excluding any carbon absorption by land use change) was 4,171 tonnes in 2019. In a recent study of the Medical Faculty, Wijesinghe et al. (2021) estimated that the annual carbon footprint per medical student was $5.64(\mathrm{SD}=2.72)$ tonnes of $\mathrm{CO}_{2}$.

\section{Summary and the way forward}

Climate action is needed at individual, institutional and national levels if countries are to reach the targets under the Paris Agreement. The sectors that require attention are energy (both electricity generation and transport), water, waste, and land use/land cover. The green measures undertaken by the University of Colombo need to be continued, and new measures adopted towards reaching the planned carbon neutrality in the future. As a signatory to the Times Higher Education Race-to-Zero initiative, the University of Colombo has pledged to become a carbon neutral university with net-zero emissions by 2040. Increasing the use of renewable energy, energy saving appliances, water conservation measures, zero waste strategies, and expanding the vegetation (especially the forest cover) is important in this regard. In achieving any planned targets under the implementation of SDG 13, commitment is essential at individual, institutional, and national levels. In developing such a commitment, attitudinal change and creating awareness among the community are also essential. There are important lessons that can also be learnt from other institutions. Strategies targeting sustainable consumption and production play a key role as they minimize energy, water, and material consumption, while minimizing waste generation. Such strategies would not only be in line with SDG 13, but also go beyond to encompass other SDGs such as SDG 12 (Responsible consumption), and SDG 15 (Life on land). Collaborative efforts and commitment at all levels, including the community and service providers such as janitorial and canteen staff are also essential for effective climate action. 


\section{References}

Eckstein, D., Hutfils, M. and Winges, M. (2019). Global climate risk index 2019: Who suffers most from extreme weather events? Weather-related loss events in 2017 and 1998 to 2017. Germanwatch.

Houghton, C.J.T. (2004). Global warming: The complete briefing. Cambridge University Press.

Intergovernmental Panel on Climate Change (IPPC). (2006). IPCC Guidelines for National Greenhouse Gas Inventories, Prepared by the National Greenhouse Gas Inventories Programme, Eggleston H.S., Buendia L., Miwa K., Ngara T. and Tanabe K. (Eds)., IGES, Japan.

Intergovernmental Panel on Climate Change (IPCC). (2011). Summary for policymakers. In O. Edenhofer, O., Pichs-Madruga,R., Sokona, Y., Seyboth, K., Matschoss, P., Kadner, S., Zwickel, T., Eickemeier, P., Hansen, G., Schlömer, S., von Stechow, C. (Eds.). IPCC special Report on Renewable Energy Sources and Climate Change Mitigation. Cambridge University Press

Kariyawasam, M. \& Lokupitiya E. (2018). Impact of university waste management practices on Greenhouse gas emissions at landfill sites. Abstract. Second International Conference on Climate Change (ICCC 2018), Colombo, Sri Lanka. The International Institute of Knowledge Management (TIIKM), 76.

Le Quéré, C., Jackson, R.B., Jones, M.W. (2020). Temporary reduction in daily global CO2 emissions during the COVID-19 forced confinement. Nature Climate Change (10), 647-653.

Lokupitiya, E.Y.K. (2002). Investment potential of energy sector projects in the Clean Development Mechanism. Department of National Planning.

Ministry of Environment. (2021). Sri Lanka: Updated nationally determined contributions. Retrieved 29 November, 2021, from https://www4.unfccc.int/sites/ndcstaging/PublishedDocuments/ Sri\%20Lanka\%20First/NDCs\%20of\%20Sri\%20Lanka-2021.pdf

Ministry of Transport. (2021). Vehicle population. Retrieved 29 November, 2021, from https://www. transport.gov.lk/web/index.php?option=com_content\&view=article\&id=26\&Itemid=146\&lang $=$ en\#vehicle-population.

United Nations. (2015). Transforming our world: The 2030 agenda for fustainable development. Retrieved 29 November, 2021, from https://www.un.org/ga/search/view_doc.asp?symbol=A/ $\mathrm{RES} / 70 / 1 \&$ Lang=E.

United Nations Framework Convention on Climate Change (UNFCCC). (2021). Retrieved 29 November, 2021, from https://unfccc.int/process-and-meetings/the-paris-agreement/the-parisagreement

Wijesinghe, P.C.I., Mathurahan, S., Wijesundere, D.S., Ranawaka, S., Arambepola, C., \& Chang, T. (2021). Estimation of the carbon footprint, its contributory factors, and knowledge and attitudes about climate change among medical students in Sri Lanka. Journal of Environment Pollution and Human Health, 9 (1), 1-5. doi: 10.12691/jephh-9-1-1. 